\title{
A 45-year-old female with a history of dyspnoea
}

\section{Case report}

A 45-year old female originally presented in January 2001 with a 25 pack-year history of tobacco use, a 2-year history of dyspnoea on exertion, fatigue and polycythaemia. Right heart catheterisation showed a pulmonary artery pressure of $54 / 26 \mathrm{mmHg}$ (mean 37) with a cardiac index of $2.3 \mathrm{~L} \cdot \mathrm{min}^{-1} \cdot \mathrm{m}^{-2}$. An open lung biopsy was performed and the samples from histopathological examination are shown in figure 1 .
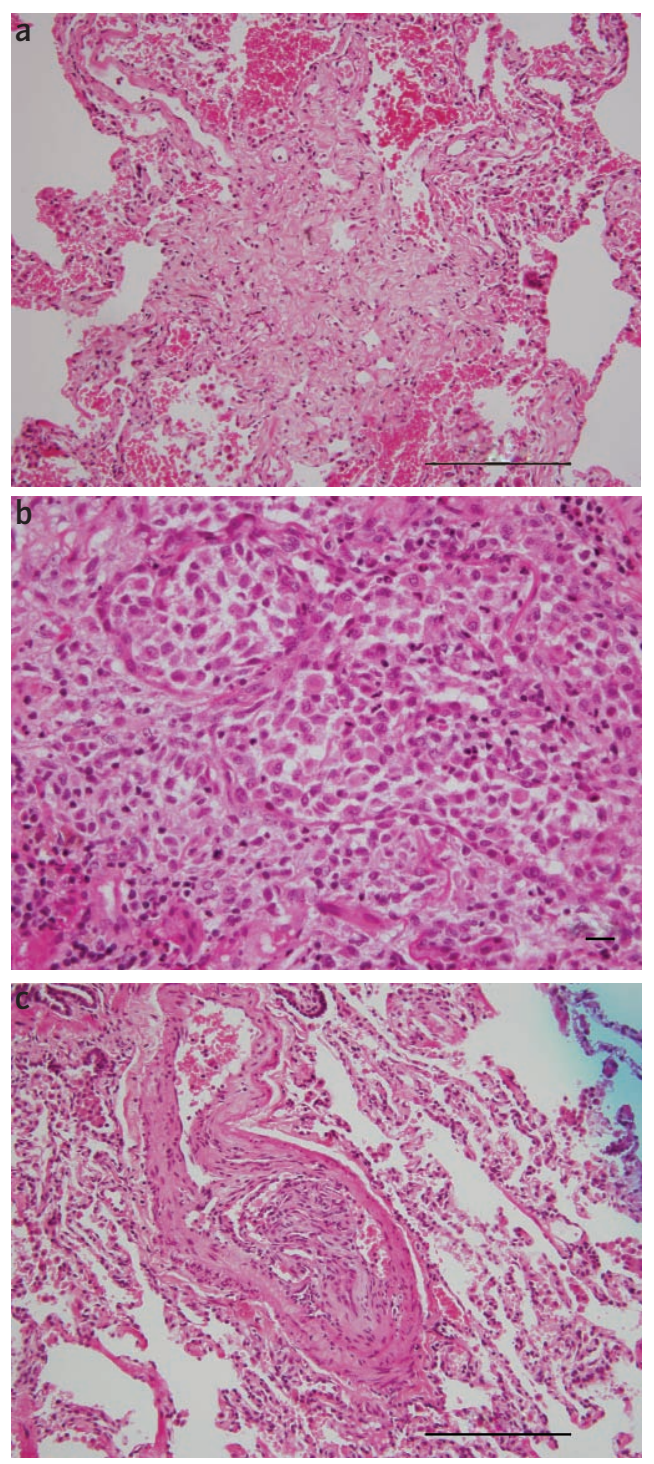

Figure 1

Open lung biopsy specimens stained with haematoxylin and eosin. Scale bars $=200 \mu \mathrm{m}(a, b)$ and $20 \mu \mathrm{m}(c)$.
K.C. Sumino

M.M. Chakinala

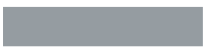

Dept of Medicine, Washington University School of Medicine, St. Louis, MO, USA.

\section{Correspondence:}

M.M. Chakinala

Washington University School of Medicine

Campus Box 8052

660 South Euclid Avenue

St. Louis

MO 63110

USA

Fax: 13144545571

E-mail:chakinalam@wustl.edu
Task 1
Interpret the histopathological findings from the open lung biopsy and suggest a diagnosis.




\section{Answer 1 \\ Figure 1a shows characteristic bronchocentric nodular lesions (stellate scars). Figure $1 \mathrm{~b}$ is a high magnification of cellular infiltrate with typical delicate and folded nuclei (histocytes). These cells were S-100 positive (data not shown). Figure 1c reveals an intra-arterial angiomatoid/plexiform lesion, resembling the changes of primary pulmonary hypertension. No significant venous abnormalities were seen. A diagnosis of pulmonary Langerhans' cell histiocytosis was made.}

The patient abstained from tobacco, but noted persistent dyspnoea and was referred for lung transplant evaluation 10 months after the initial diagnosis. At the initial evaluation in November 2001, she was placed in functional class II, on supplemental oxygen, diuretics and anticoagulants. Physical examination disclosed an accentuated second heart sound and a 2/6 holosystolic murmur, which was consistent with tricuspid regurgitation. Pulmonary function studies were remarkable only for an isolated reduction in the diffusing capacity and she managed $288 \mathrm{~m}$ during a 6-minute walk test (6MWT). Chest radiography and high-resolution computed tomography (HRCT) were performed (figures 2 and 3).

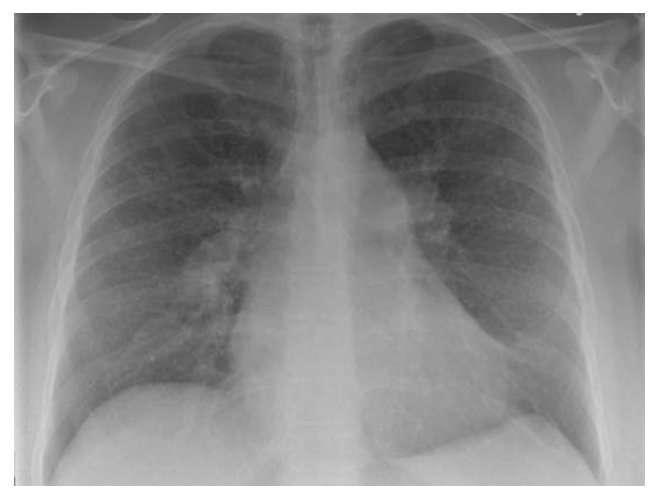

Figure 2

Chest radiograph.

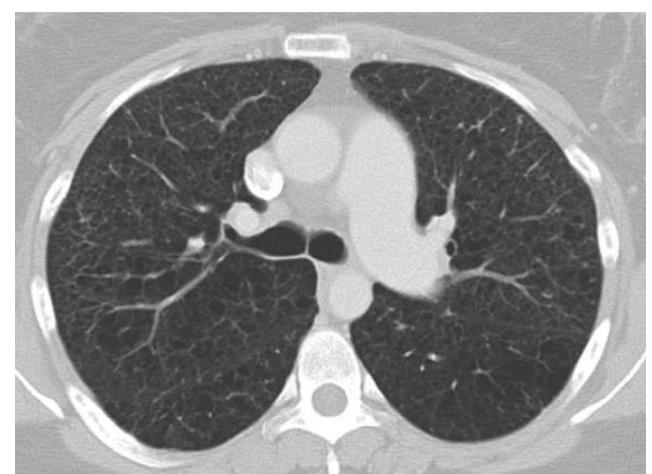

Figure 3

HRCT scan

\section{Task 2 \\ Interpret the chest radiograph and the HRCT scan.}

Evaluations for chronic thromboembolic disease, sleep-disordered breathing, collagen-vascular disease and congenital cardiac anomalies were unrevealing. Right heart catheterisation showed significant worsening of pulmonary hypertension.

\section{Task 3}

At this stage, how would you progress with the management of this patient? 


\section{Answer 2}

The chest radiograph showed large pulmonary arteries and interstitial infiltrates. The HRCT scan revealed innumerable small thin-walled cysts predominantly in the upper lobes, and enlarged pulmonary arteries.

\section{Answer 3}

The patient was placed on the United Network for Organ Sharing (UNOS) waiting list for lung transplantation and bosentan $125 \mathrm{mg}$ b.i.d. was initiated.

After 6 months of treatment, the patient noted subjective improvement, walked 79 m further during a 6MWT and remained in functional class II (table 1). Right heart catheterisation performed 1 year after demonstrated a 14\% decline of the mean pulmonary arterial pressure (PAP) and a 50\% improvement in the cardiac index $(\mathrm{Cl})$. Eighteen months after starting treatment, she continued to work full time, maintained a busy lifestyle, remained in functional class II and was removed from the transplant list. After 2 years on bosentan, 6MWT distance declined by $\sim 70 \mathrm{~m}$, although she was still in functional class II. Six months later, right heart catheterisation confirmed the worsening of pulmonary haemodynamics to the pre-treatment level. During this 2.5-year period, both the forced expiratory volume in one second (FEV1) and forced vital capacity (FVC) had declined by $400 \mathrm{~mL}$.

\section{Discussion}

Pulmonary Langerhans' cell histiocytosis (PLCH) is a smoking-related interstitial lung disease characterised by proliferation and infiltration of Langerhans' cells into the lung parenchyma [1]. The clinical course of PLCH in adults is unpredictable, ranging from spontaneous regression to progressive respiratory failure even after smoking cessation $[2,3]$. Pulmonary hypertension $(\mathrm{PH})$ is a well-known complication of $\mathrm{PLCH}$, which is almost invariably present and often severe [4]. In the latest classification scheme, PH associated with PLCH is distinguished from the categories of pulmonary arterial hypertension (PAH) and $\mathrm{PH}$ associated with lung diseases and/or hypoxaemia [5]. There is no proven therapy for $\mathrm{PLCH}$ patients with $\mathrm{PH}$, and treatment during the waiting period for lung transplantation is challenging. The case presented here involved a patient with $\mathrm{PLCH}$ with severe $\mathrm{PH}$, who experienced improvement and prolonged stabilisation for $>2$ years with bosentan, an oral endothelin (ET)-1 receptor antagonist.

ET-1 is a potent endogenous vasoconstrictor and smooth muscle mitogen that has been implicated in the pathogenesis of $\mathrm{PH}[6,7]$. Patients with idiopathic pulmonary arterial hypertension (IPAH) have increased plasma levels and

\section{Table 1 Pulmonary haemodynamics and pulmonary function tests}

\begin{tabular}{|c|c|c|c|c|c|c|}
\hline Date & 01.2001 & 11.2001 & 06.2002 & 12.2002 & 12.2003 & 06.2004 \\
\hline Status & $\begin{array}{c}\text { Initial } \\
\text { diagnosis }\end{array}$ & $\begin{array}{l}\text { Listed for lung } \\
\text { transplant and } \\
\text { bosentan started }\end{array}$ & $\begin{array}{l}6 \text { months } \\
\text { after } \\
\text { bosentan }\end{array}$ & $\begin{array}{l}12 \text { months } \\
\text { after } \\
\text { bosentan }\end{array}$ & $\begin{array}{l}24 \text { months } \\
\text { after } \\
\text { bosentan }\end{array}$ & $\begin{array}{l}30 \text { months } \\
\text { after } \\
\text { bosentan }\end{array}$ \\
\hline $\begin{array}{l}\text { PAP mmHg } \\
\text { (mean PAP) }\end{array}$ & $54 / 26(37)$ & $100 / 44(64)$ & & $86 / 35(55)$ & & $80 / 30(50)$ \\
\hline CO/CI (Fick) & $3.8 / 2.3$ & $3.4 / 2.0$ & & $5.4 / 3.1$ & & $3.4 / 1.9$ \\
\hline $\mathrm{A}-\mathrm{VO}_{2}$ difference & $N A$ & 5.8 & & 4.1 & & 6.8 \\
\hline$R A P$ & $N A$ & 12 & & 10 & & 10 \\
\hline PAWP & 18 & $N A$ & & 12 & & 15 \\
\hline$P V R$ & 389 & $N A$ & & 637 & & 823 \\
\hline $6 M W T m$ & & 288 & 367 & 367 & 295 & $N A$ \\
\hline Resting $S P, 0_{2} \%$ & & 94 & & 94 & & 92 \\
\hline$F V C L$ & & 3.5 & & 3.31 & & 3.05 \\
\hline$F E V_{1} L$ & & 2.52 & 2.44 & 2.43 & 2.03 & 2.1 \\
\hline TLC \% predicted & & 105 & & $N A$ & & 115 \\
\hline DL,Co \% predicted & & 29 & & $N A$ & & 26 \\
\hline Weight kg & & 68 & 72 & 78 & 80 & 80 \\
\hline \multicolumn{7}{|c|}{$\begin{array}{l}C O \text { : cardiac output; } A-\mathrm{VO}_{2} \text { : arteriovenous oxygen difference; RAP: right atrial pressure; PAWP: pulmonary arterial } \\
\text { wedge pressure; } P V R \text { : pulmonary vascular resistance; } \mathrm{SP}_{2} \mathrm{O}_{2} \text { : arterial oxygen saturation measured by pulse oximetry; } \\
T L C \text { : total lung capacity; } D L, C O \text { : carbon monoxide diffusing capacity of the lung; } N A \text { : not available. }\end{array}$} \\
\hline
\end{tabular}


overexpression of ET-1 in the pulmonary vasculature [8]. The dual ET-1 receptor antagonist, bosentan, has been shown to improve exercise capacity and short-term haemodynamics in patients with PAH [9]. Furthermore, bosentan delays progression of the condition, as defined by a composite end-point of death, hospitalisation for $\mathrm{PH}$, or a need for additional medical therapy [9]. In the patient presented here, the timing of improvement (i.e. lengthy period after tobacco cessation), relative stability of lung function, duration of follow-up and sequential haemodynamic data strongly suggest that her condition was positively influenced by treatment of $\mathrm{PH}$ with bosentan.

The degree of $\mathrm{PH}$ associated with interstitial lung disease (other than in autoimmune diseases [10]) is typically not severe [11]. However, recent studies have indicated that moderate-to-severe $\mathrm{PH}$ could be encountered in patients with certain interstitial lung diseases, such as sarcoidosis and $\mathrm{PLCH}[4,12,13]$. In a recent report, patients with advanced $\mathrm{PLCH}$, had significantly higher PAP and lower $\mathrm{Cl}$ than comparable groups with chronic obstructive pulmonary disease or idiopathic pulmonary fibrosis [4]. Histopathological analysis showed proliferative changes of arteries and veins. However, the plexiform lesions that were present in this case have not been described to date. Haemodynamic derangements do not correlate with the magnitude of parenchymal disease in $\mathrm{PLCH}$, and sequential histopathology in individual cases has demonstrated progression of vascular changes in spite of stability or improvement of parenchymal abnormalities. As a result, pulmonary vascular disease in $\mathrm{PLCH}$ appears to be independent of the parenchymal disease. The identification of veno-occlusive pathology may explain why some PLCH patients developed pulmonary oedema after starting prostacyclin, as discussed by FARTOUKH et al. [4], thus raising concern for the use of vasodilators in this group of patients. In contrast, the patient presented here showed no such deterioration and, in fact, demonstrated initial improvement and stabilisation with bosentan for an extended period of time, which may be explained by the exclusive arterial changes seen on her biopsy, or possibly due to the anti-proliferative effects of bosentan compared with the only minimal acute vasodilatory effect.

In conclusion, bosentan should be considered in patients with significant $\mathrm{PH}$ associated with PLCH with potential benefits similar to patients in the category of PAH.

\section{References}

1. Travis WD, Borok Z, Roum JH, et al. Pulmonary Langerhans cell granulomatosis (histiocytosis X). A clinicopathologic study of 48 cases. Am J Surg Pathol 1993; 17: 971-986.

2. Mogulkoc N, Veral A, Bishop PW, Bayindir U, Pickering CA, Egan JJ. Pulmonary Langerhans' cell histiocytosis: radiologic resolution following smoking cessation. Chest 1999; 115: 1452-1455.

3. Vassallo R, Ryu JH, Schroeder DR, Decker PA, Limper AH. Clinical outcomes of pulmonary Langerhans'-cell histiocytosis in adults. N Engl J Med 2002; 346: 484-490.

4. Fartoukh M, Humbert M, Capron F, et al. Severe pulmonary hypertension in histiocytosis X. Am J Respir Crit Care Med 2000; 161: 216-223.

5. Simonneau G, Galie N, Rubin LJ, et al. Clinical classification of pulmonary hypertension. J Am Coll Cardiol 2004; 43: Suppl. $12,5 S-12 S$.

6. MacLean MR. Endothelin-1: a mediator of pulmonary hypertension? Pulm Pharmacol Ther 1998; 11: 125-132.

7. Chen YF, Oparil S. Endothelial dysfunction in the pulmonary vascular bed. Am J Med Sci 2000; 320: 223-232.

8. Giaid A, Yanagisawa M, Langleben D, et al. Expression of endothelin-1 in the lungs of patients with pulmonary hypertension. N Engl J Med 1993; 328: 1732-1739.

9. Rubin LJ, Badesch DB, Barst RJ, et al. Bosentan therapy for pulmonary arterial hypertension. $N$ Engl J Med 2002; 346: 896-903.

10. Chang $B$, Wigley $F M$, White $B$, Wise RA. Scleroderma patients with combined pulmonary hypertension and interstitial lung disease. J Rheumatol 2003; 30: 2398-2405.

11. Harari S, Comel A. Pulmonary Langerhans cell histiocytosis. Sarcoidosis Vasc Diffuse Lung Dis 2001; 18: 253-262.

12. Harari S, Simonneau G, De Juli E, et al. Prognostic value of pulmonary hypertension in patients with chronic interstitial lung disease referred for lung or heart-lung transplantation. J Heart Lung Transplant 1997; 16: 460-463.

13. Shorr AF, Davies DB, Nathan SD. Outcomes for patients with sarcoidosis awaiting lung transplantation. Chest 2002; 122: 233-238. 